\title{
Biallelic Mutations in Huntington Disease: A New Case with Just One Affected Parent, Review of the Literature and Terminology
}

\author{
Wendy R. Uhlmann, ${ }^{1,2 *}$ Maria S. Peñaherrera, ${ }^{3,4}$ Wendy P. Robinson, ${ }^{3,4}$ Jeff M. Milunsky, ${ }^{5}$ \\ Jane M. Nicholson, ${ }^{1,6}$ and Roger L. Albin ${ }^{7,8}$ \\ ${ }^{1}$ Division of Molecular Medicine and Genetics, Department of Internal Medicine, University of Michigan, Ann Arbor, Michigan \\ ${ }^{2}$ Department of Human Genetics, University of Michigan, Ann Arbor, Michigan \\ ${ }^{3}$ Department of Medical Genetics, University of British Columbia, Vancouver, British Columbia \\ ${ }^{4}$ Child and Family Research Institute, Vancouver, British Columbia \\ ${ }^{5}$ Center for Human Genetics Inc., Cambridge, Massachusetts \\ ${ }^{6}$ Department of Obstetrics and Gynecology, University of Michigan, Ann Arbor, Michigan \\ 'Department of Neurology, University of Michigan, Ann Arbor, Michigan \\ ${ }^{8}$ VA Ann Arbor Healthcare System, Geriatrics Research, Education, and Clinical Center, Ann Arbor, Michigan
}

Manuscript Received: 8 September 2014; Manuscript Accepted: 22 January 2015

Patients with biallelic mutations for Huntington disease (HD) are rare. We present a 46-year-old female with two expanded Huntingtin (HTT) alleles with just one known affected parent. This is the first reported patient with molecular studies performed to exclude HTT uniparental disomy (UPD). The proband had biparental inheritance of $H T T$ alleles (42/44 CAG repeats). Given the negative UPD results, the proband's unaffected mother either had a reduced penetrance allele that expanded into the full mutation range during transmission to our patient or an unknown full HTT mutation and died before symptom onset, unlikely given no family history of $\mathrm{HD}$ and asymptomatic at age 59. We made the novel observation in our literature review that most patients with biallelic HD did not have two full HTT mutations. Most had one HTT allele that was in the intermediate or reduced penetrance ranges or 40 CAG repeats, the lowest limit of the full mutation range. Although the number of patients is small, when an allele in these size ranges was present, generally the age of $\mathrm{HD}$ onset was in the 50s. If the second HTT allele had $>45$ repeats, then onset was typically 20 s30s. While similar ages of onset have been reported for patients with one or two HTT mutations, patients with biallelic mutations may have later onset if an expanded $H T T$ allele has $\leq 40$ CAG repeats. Finally, we propose that "biallelic mutations" or "compound heterozygosity" are more accurate descriptive terms than "homozygosity" when there are two non-identical expanded HTT alleles. () 2015 Wiley Periodicals, Inc.

Key words: Huntington disease (HD); biallelic mutations; biallelic Huntington disease; compound heterozygote; compound heterozygosity; homozygotes; homozygosity; reduced penetrance alleles; intermediate alleles; uniparental disomy (UPD)
How to Cite this Article:

Uhlmann WR, Peñaherrera MS, Robinson WP, Milunsky JM, Nicholson JM, Albin RL. 2015. Biallelic mutations in Huntington disease: A new case with just one affected parent, review of the literature and terminology.

Am J Med Genet Part A 167A:1152-1160.

\section{INTRODUCTION}

Huntington disease (HD) is an autosomal dominantly inherited neurological condition with progressive cognitive, motor, and psychiatric symptoms. The mean age of onset is 35-44 years [Warby et al., 1998]. Huntington disease is caused by a CAG trinucleotide repeat expansion in the HTT gene on chromosome 4 with repeat numbers defined as: full mutation (40 or more), reduced penetrance (36-39), intermediate (27-35) and normal (26 or less) [ACMG/ASHG Huntington Disease Genetic Testing Working Group 1998; Potter et al., 2004]. Intermediate and

\section{Conflict of interest: none.}

*Correspondence to:

Wendy R. Uhlmann, MS, CGC, University of Michigan, Department of Internal Medicine, Division of Molecular Medicine and Genetics 300 North Ingalls, NI3 A03, SPC 5419 Ann Arbor, MI 48109.

Email: wuhlmann@umich.edu

Article first published online in Wiley Online Library

(wileyonlinelibrary.com): 3 March 2015

DOI 10.1002/ajmg.a.37009 
reduced penetrance alleles are unstable and can expand into the full mutation range when transmitted, primarily in paternal transmissions [Goldberg et al., 1993, 1995; Maat-Kievit et al., 2001a; Semaka et al., 2006, 2010, 2013a; Brocklebank et al., 2009; Sequeiros et al., 2010; Aziz et al., 2011; Semaka and Hayden, 2014].

The prevalence of HD is estimated to be $12-15 / 100,000$ in individuals of European descent [Warby et al., 1998; Evans et al., 2013; Fisher and Hayden, 2014]. Patients with biallelic CAG expansion alleles have previously been described as "homozygous", but we suggest that the terms "biallelic" or "compound heterozygous" would be more accurate. Biallelic HD has occurred in diverse ethnic groups (Table I) and the prevalence in two large family studies of affected individuals ranged from $0.1 \%, \mathrm{~N}=1007$ [Kremer et al., 1994] to $0.4 \%, N=263$ [Alonso et al., 2002]. Studies of patients with biallelic HD have generally reported similar features, age of onset, and disease course as heterozygous individuals [Young et al., 1986; Wexler et al., 1987; Myers et al., 1989; Kremer et al., 1994; Durr et al., 1999; Laccone et al., 1999; Alonso et al., 2002; Costa et al., 2003]. One study [Squitieri et al., 2003a] suggested that the clinical course is more severe and progression more rapid in patients with biallelic HD.

In the absence of a second known affected parent and after excluding technical artifacts or limitations (e.g., primer issues, somatic mosaicism, very long repeats requiring Southern blotting for identification), possible explanations for biallelic HD include: (1) non-paternity (non-maternity is implausible except in IVF cases with egg donation or a father and present partner raising a child from an undisclosed previous relationship) (2) an intermediate or reduced penetrance HTT allele in the unaffected parent (3) a full mutation allele in an asymptomatic parent who died prematurely or has not lived long enough to develop symptoms (unlikely if no family history of HD) or (4) HTT uniparental isodisomy.

Uniparental disomy (UPD) occurs in a number of genetic conditions [Engel, 2006; Kotzot, 2008; Yamazawa et al., 2010]. Maternal UPD for chromosome 4 has been reported [Kuchinka et al., 2001; Spena et al., 2004; Middleton et al., 2006; Cottrell et al., 2012; Ding et al., 2012] and there is one published paternal segmental UPD(4) clinical report [Elli et al., 2012]. No reports of UPD for HD were identified in our literature review.

We present a 46-year-old female with biallelic HTT mutations with one affected parent (father), in whom we performed UPD testing to rule out the possibility that she inherited two paternal HTT alleles. We also reviewed the literature and summarize the genetic test results and ages of onset reported to date in individuals with biallelic HD.

\section{MATERIALS AND METHODS}

This study was approved by the University of Michigan Medical School Institutional Review Board, which operates under 45 CFR 46. Both the subject of this report and her husband provided informed consent.

\section{Clinical Report}

The 46-year-old female patient was evaluated by a neurologist (RLA) because of a 1-2 year history of progressive incoordination and declining memory. She had a history of recurrent depression requiring medical treatment. The patient reported increasing difficulty with performing her manual labor job. Family members noted involuntary limb movements. Saccadic eye movements were slowed with involuntary head turning and involuntary blinking during saccade initiation. There was a mild intermittent rotatory head tremor. Rapid finger movements were moderately slowed, tone and casual gait were normal, with mildly impaired tandem gait. Choreoathetosis was noted in fingers and toes.

Limited family history information (Fig. 1) and medical records were available. The patient's father was cared for by RLA and had HD, confirmed by autopsy, with onset in his early 50s and deceased at age 68. The patient had a brother and a sister. Her brother, also followed by RLA, developed HD in his late 20s and died at age 43; no genetic testing or autopsy was performed. By family report, her asymptomatic 37-year-old sister had positive presymptomatic genetic test results for HD. The children of the patient's siblings, two daughters and a son, were reported to be asymptomatic. The patient's mother died at age 59 of a cerebral aneurysm and was not reported to have a family history of HD or any other neurologic conditions. There was no parental consanguinity. The patient was diagnosed with manifest $\mathrm{HD}$ at age 46 .

\section{CAG Repeat Size Analysis and Uniparental Disomy Studies}

A blood sample was obtained from the patient and DNA was isolated. The HTT gene was amplified in three separate reactions using the polymerase chain reaction (PCR) followed by capillary electrophoresis of the fluorescent PCR products to determine the CAG triplet repeat lengths. The three reactions amplify the $\mathrm{CAG}_{n}$ $+C_{C G}$ region, the $C_{C} G_{n}$ region alone and the $C_{A G}$ region alone. These tests may not detect expansions of greater than 80 trinucleotide repeats. A Coriell cell line (NA13510) with 15 and 44 CAG repeats was used as a positive control (sequencing confirmed CAG repeat numbers)

Molecular polymorphism studies were performed to rule out the possibility that the patient had inherited two copies of the paternal HTT allele as a result of UPD. The patient's mother was deceased so no maternal DNA was available. DNA was isolated from the patient's blood sample and her deceased affected father's brain tissue. Markers used (Supplemental Online Table SI) included microsatellites flanking the HTT gene [primer information and mapping data is available for all microsatellites through the National Center for Biotechnology Information (NCBI)]. Markers were genotyped by PCR using fluorescently labeled primers, with PCR products quantified on an ABI 310 Prism Genetic Analyzer (ABI, Foster City, CA).

\section{RESULTS}

The result from the first reaction amplifying the $\mathrm{CAG}_{\mathrm{n}}+\mathrm{CCG}_{\mathrm{n}}$ region was 43 and 45 repeats. The result from the second reaction amplifying the $\mathrm{CCG}_{\mathrm{n}}$ region alone was seven repeats. Amplifying 


\section{$\sqrt{1} \mathrm{E} \frac{\bar{x}}{2}$}

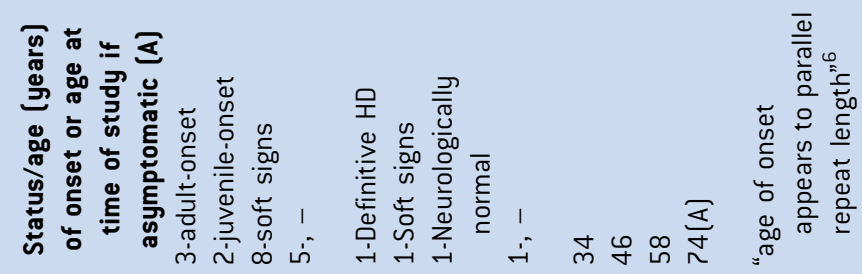

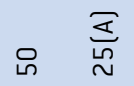

$m \approx \stackrel{m}{\sim}$

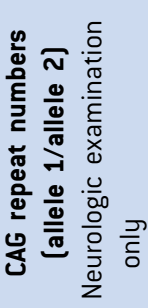

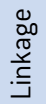

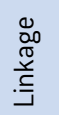

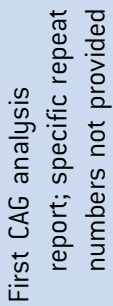

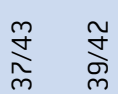

$\stackrel{m}{\stackrel{f}{q}}$

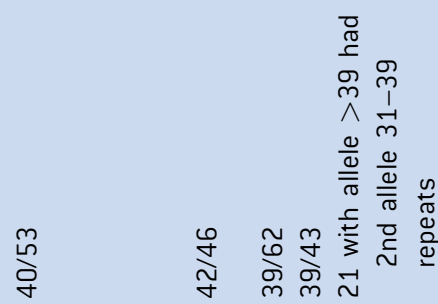

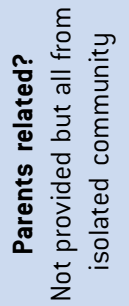
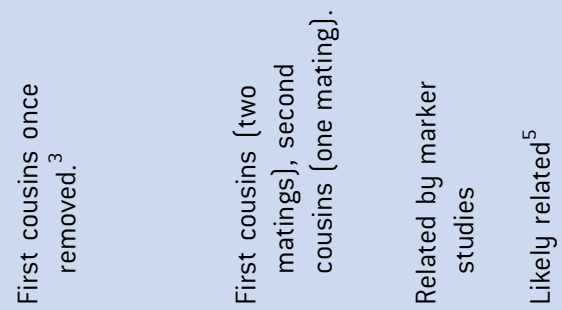

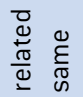

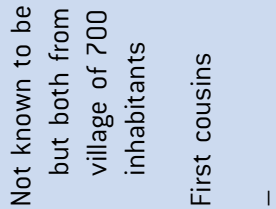

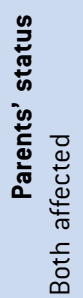
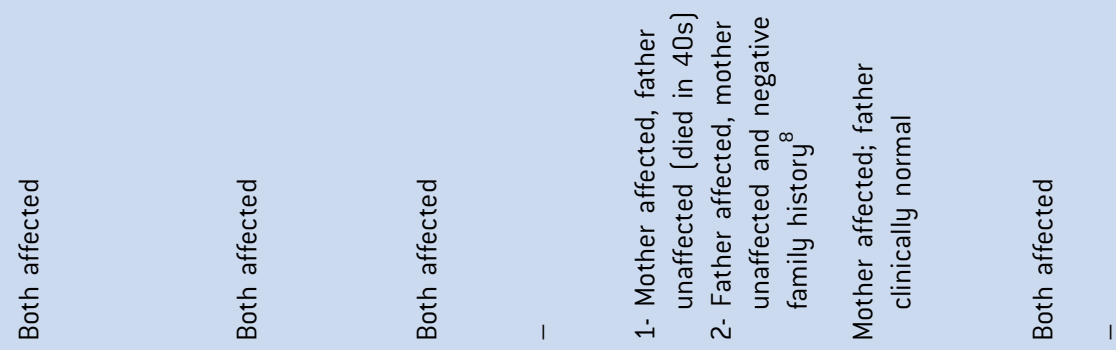

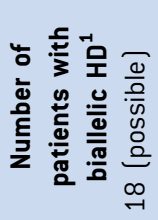
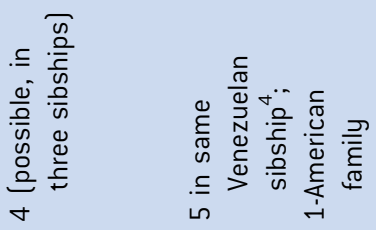

$+\stackrel{N}{\sim}$
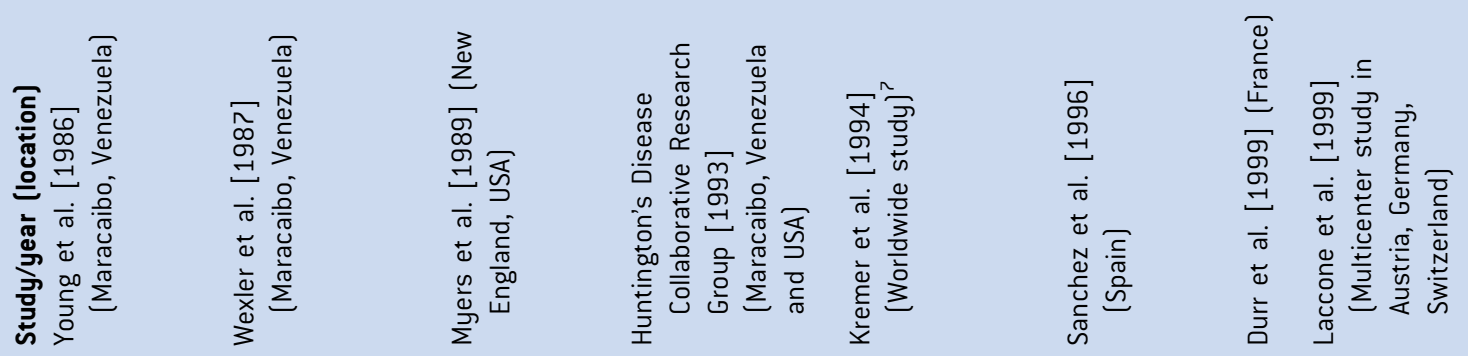

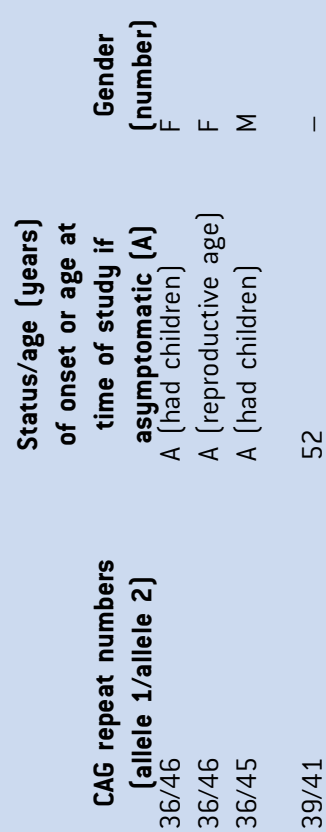

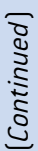

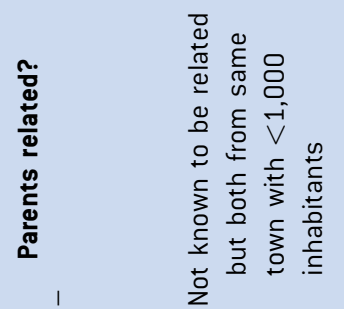

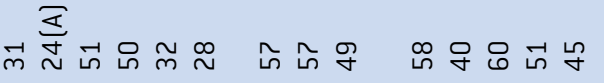

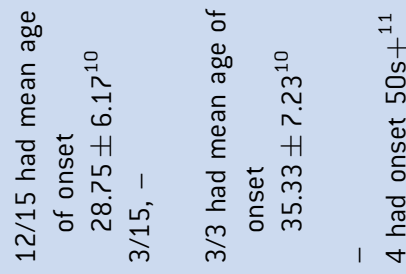

$\underset{\substack{\infty \\ m}}{\varpi}$
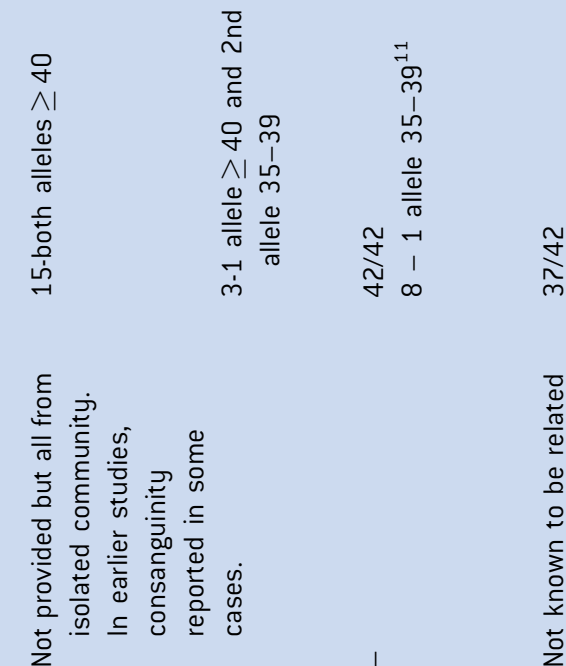

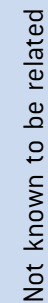

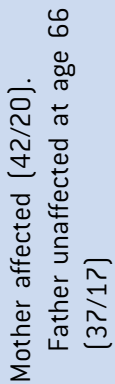

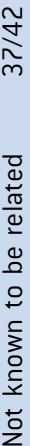

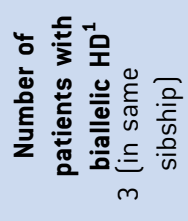

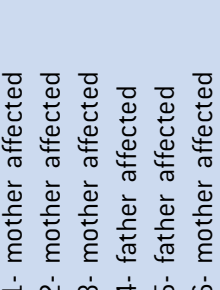
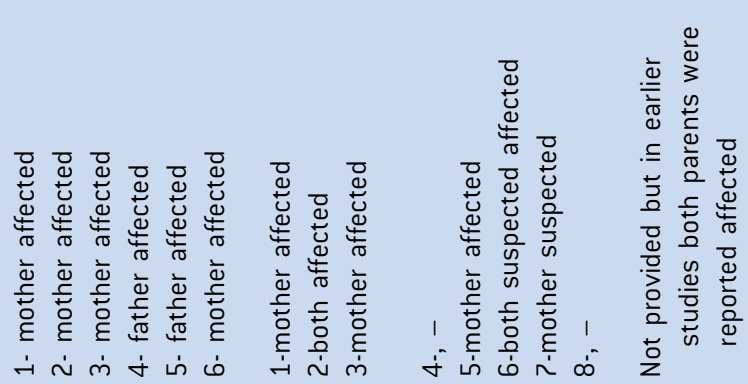

$\stackrel{\infty}{\rightarrow-1}$

윽
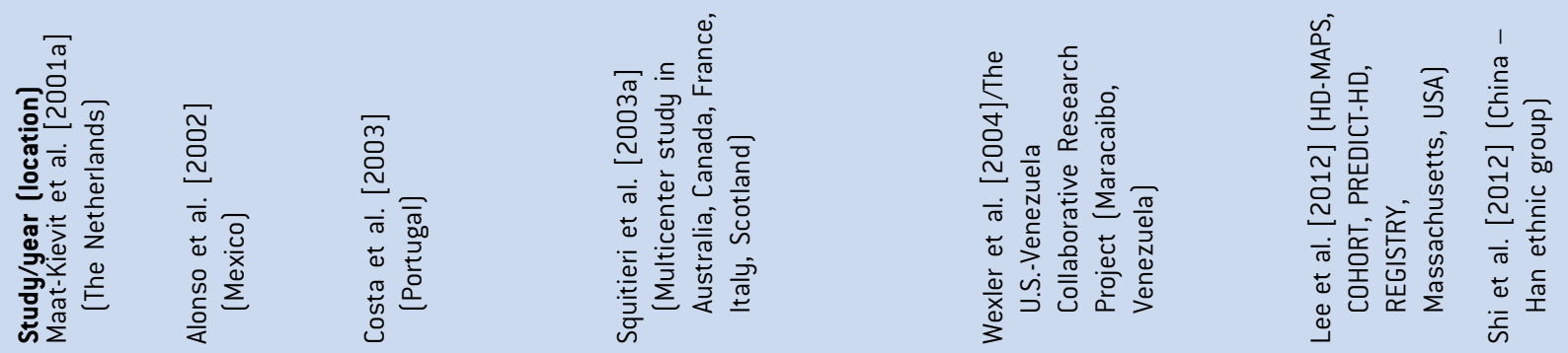


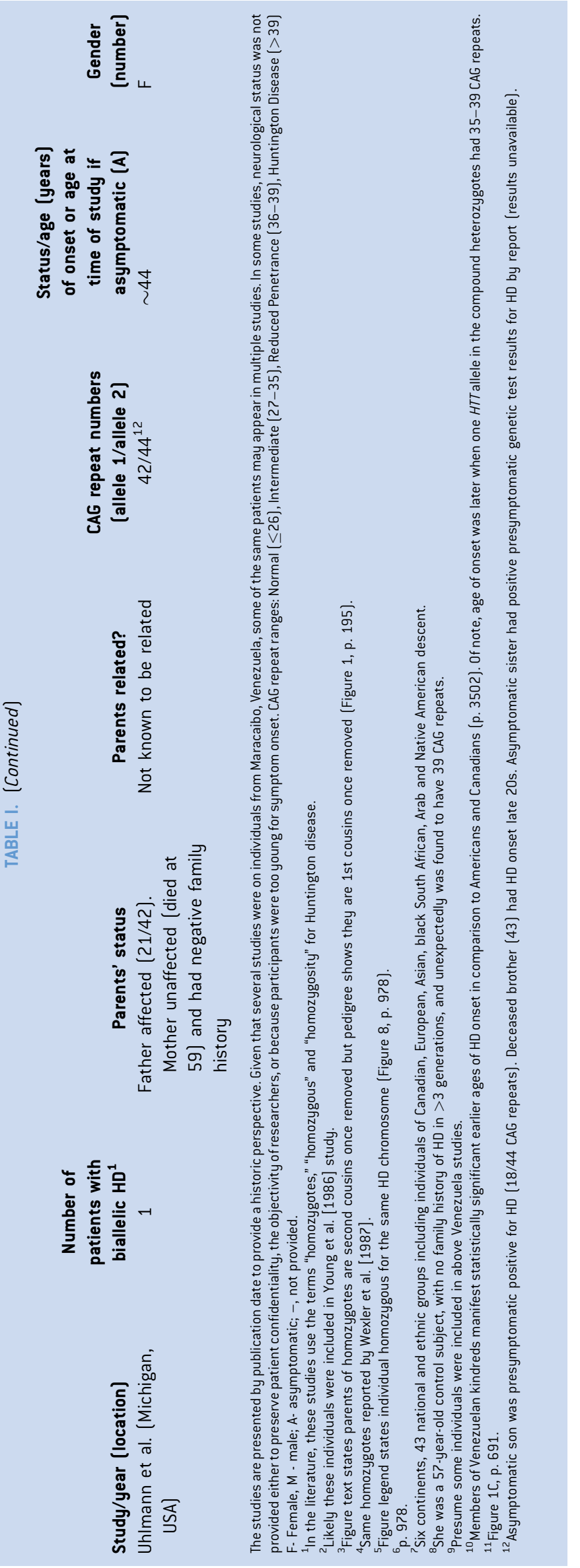

the CAG region alone yielded 42 and 44 repeats. No normal alleles were seen. A second blood sample was obtained from the patient, which confirmed these results. As two different allele sizes were observed, a regional deletion or allele drop-out was unlikely. A combination of allele drop-out and somatic mosaicism of the single paternal allele remained a possibility. The CAG studies performed on the father's brain tissue yielded 21 and 42 repeats. The patient's asymptomatic son had presymptomatic genetic testing and had 18 and 44 CAG repeats; this sample was run concurrently with the mother's sample. Therefore, analysis of samples from the patient's father and son further confirmed the presence of two allele sizes of 42 and 44 repeats.

When testing for UPD in the patient, a non-paternal (presumably maternal) allele was noted for five chromosome 4 markers used including D4S127, which is located less than $40 \mathrm{~kb}$ telomeric to the first exon of the HD gene, and D4S412. The D4S412 marker was informative on the centromeric side and is located approximately $100 \mathrm{~kb}$ from the centromeric side of the HD gene. Thus, segmental UPD was essentially ruled out.

\section{DISCUSSION}

This is the first reported patient with biallelic HTT mutations where UPD was excluded. The patient had two HTT alleles in the full mutation range and one of the higher combinations of CAG repeat numbers (42/44) reported to date (Table I). Only one parent had diagnosed HD and the patient's parents were not related and did not come from a small community.

Given that only the patient's father was known to be affected with $\mathrm{HD}$ and the rarity of biallelic mutations for this condition, it was important to confirm this finding and determine etiology. Uniparental disomy was regarded as an unlikely cause because it has not been documented for HD and all but one patient [Elli et al., 2012] with reported UPD(4) to date have been maternal in origin [Kuchinka et al., 2001; Spena et al., 2004; Middleton et al., 2006; Cottrell et al., 2012; Ding et al., 2012]. We excluded full and segmental paternal UPD. Non-maternity is quite rare and there was no reason to consider it in this family. We believe that the patient's mother either had (1) a reduced penetrance allele that expanded into the full mutation range during transmission to the patient (a rare event) or (2) an unknown full HTT mutation and died before symptom onset (unlikely given no family history of HD and lack of symptoms at age 59).

\section{Unaffected Parent Could Have a Reduced Penetrance or Intermediate Allele}

When a patient with HD and biallelic HTT mutations has just one affected parent, the unaffected parent with no family history of HD could have a reduced penetrance or an intermediate HTT allele. This HTT allele could be stably transmitted, contract (less common) or expand, even into the full mutation range. In the general population, approximately $1-6 \%$ of individuals have an intermediate allele and approximtely $1-3 \%$ have a reduced penetrance allele [Huntington's Disease Collaborative Research Group, 1993; Kremer et al., 1994; Goldberg et al., 1995; Raskin et al., 2000; Maat-Kievit et al., 2001a, b; Tassiker et al., 2006; 


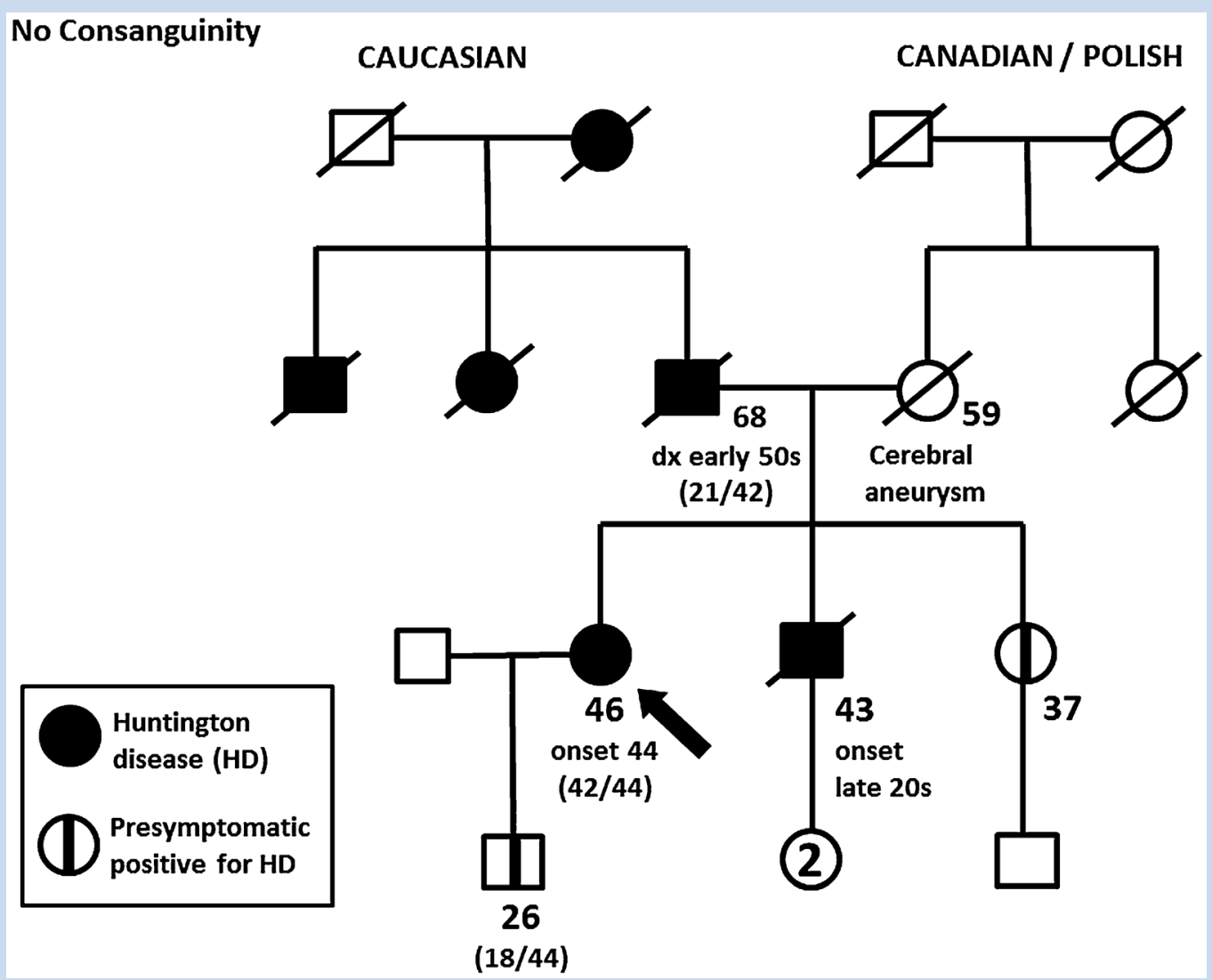

FIG. 1. Pedigree. The known CAG repeat numbers for each HIT allele are in parentheses.

Sequeiros et al., 2010; Squitieri and Jankovic, 2012; Semaka et al., 2013b; Semaka and Hayden, 2014].

In our literature review, we noted a number of patients with HD and biallelic mutations with just one affected parent and most of these patients had an intermediate or reduced penetrance allele (Table I). There were three reported patients with both HTT alleles in the full mutation range and just one parent (mother) affected: 40/ 53 repeats [Sanchez et al., 1996], 42/44 and 40/44 repeats [Squitieri et al., 2003a]. Of note, one of Squitieri et al.'s patients had the identical number of CAG repeats as the patient reported here, but a later age of onset (57).

We think it is unlikely that the present patient's mother had an intermediate HTT allele because except for one reported patient [Semaka et al., 2015], maternal expansion of an intermediate allele into a full HD mutation has not been reported [Goldberg et al., 1993; Kremer et al., 1995; Maat-Kievit et al., 2001a; Semaka et al., 2006, 2010; Brocklebank et al., 2009; Semaka and Hayden, 2014]. Although rare, maternal expansions of reduced penetrance HTT alleles into the full mutation range have been reported [Sanchez et al., 1997; Laccone and Christian, 2000; Brocklebank et al., 2009; Aziz et al., 2011] and this may have occurred with the patient reported here.

\section{Higher Prevalence of an HTT Allele $\leq 40$ repeats in Biallelic HD and Age of Onset}

In our review of the literature (Table I), we made the novel observation that most patients with $\mathrm{HD}$ and biallelic mutations (reported as homozygous HD) did not have two full mutations. Most patients had one HTT allele in the reduced penetrance or intermediate ranges or at $40 \mathrm{CAG}$ repeats, the lower limit of the full mutation range. Excluding the Venezuela cases (where overall age of onset is thought to be earlier in this extended pedigree), there were 12 patients with onset at age 49 or older and 11 had an allele with 40 or less repeats (the exception is Squitieri et al., [2003a] patient with $42 / 44$ repeats). Five patients had onset at ages 22-33 and all had an allele $>45$ repeats. For the three patients with both alleles $>40$, age of onset ranged from 33 to 57 .

It was suggested in the literature that patients with biallelic mutations have a similar age of onset as do heterozygotes [Young et al., 1986; Wexler et al., 1987; Myers et al., 1989; Kremer et al., 1994; Durr et al., 1999; Laccone et al., 1999; Alonso et al., 2002; Costa et al., 2003]. Lee et al. [2012] concluded that the presence of a second HTT allele did not significantly impact the age of onset of motor symptoms of HD, which they found was primarily deter- 
mined by the larger expanded allele. In our compilation of reports (Table I), patients who had biallelic mutations with an expanded $H T T$ allele $\leq 40$ CAG repeats generally had symptoms starting in their 50s, which is later than the mean age of HD onset [Warby et al., 1998]. This interpretation is based on a limited number of patients and therefore should be corroborated with a larger number of patients with biallelic mutations. While a later age of HD onset has also been seen in individuals with large normal alleles [Snell et al., 1993; Djousse et al., 2003; Aziz et al., 2009], our interpretation is problematic because it would imply that patients with no normal HTT alleles may have a later age of onset than those with just one expanded allele; further investigation is warranted.

\section{Terminology}

In our literature review, "homozygotes" was the term universally used to describe individuals with two expanded HTT alleles. We propose that "biallelic HD/mutations/expansions" (preferred) or "compound heterozygotes" rather than "homozygotes" are more accurate terms to describe individuals with two expanded HTT alleles not identical by descent. The terms "biallelic mutations" and "compound heterozygosity" are used with other autosomal dominant conditions including familial hypercholesterolemia [Yao et al., 2012; Youngblom and Knowles, 2014] facioscapulohumeral muscular dystrophy [Scionti et al., 2012] and hereditary colorectal cancer [Lindor, 2009].

\section{Genetic Counseling}

Biallelic HD has significant risk implications for offspring (obligate heterozygotes for an expanded HTT allele), the patient's siblings (75\% risk to have one or both expanded HTT alleles), the patient's parents (obligate heterozygotes) and other relatives. There are challenging counseling and ethical issues to consider when biallelic HD is discovered [Alonso et al., 2002; Costa et al., 2003; Squitieri et al., 2003b]. The ages of children, timing of disclosure, "do no harm" and the preservation of the "right not to know" are significant considerations.

When a patient with biallelic HD is identified with just one affected parent (and parentage is certain) and the other parent has no family history of HD, a likely explanation is that the unaffected parent has an intermediate or reduced penetrance HTT allele that has either been stably transmitted or expanded. If the patient with biallelic HD has two full mutations and the mother is unaffected, it is highly likely that she has a reduced penetrance allele. An unaffected father could have a reduced penetrance (more likely) or an intermediate allele that expands upon transmission.

Although the number of reports is limited, we noted in our review that most patients with biallelic HD do not have two full mutations and those with one expanded $H T T$ allele of $\leq 40$ CAG repeats generally had onset in their 50s. This could have significant implications for recurrence risks. Analyses of more individuals with biallelic HD and comparison of both of their HTT alleles to the known mean ages of onset for the CAG repeats will be important for both assessing if patients with one or two HTT mutations have differential ages of onset and providing accurate onset information.

\section{ACKNOWLEDGMENT}

We thank Dr. Tanya Nelson, Department of Pathology and Laboratory Medicine, Children's and Women's Health Centre of $\mathrm{BC}$, for providing some of the molecular testing results.

\section{REFERENCES}

Alonso ME, Yescas P, Rasmussen A, Ochoa A, Macias R, Ruiz I, Suastegui R. 2002. Homozygosity in Huntington's disease: new ethical dilemma caused by molecular diagnosis. Clin Genet 61:437-442.

American College of Medical Genetics/American Society of Human Genetics Huntington Disease Genetic Testing Working Group. 1998. ACMG/ASHG statement: laboratory guidelines for Huntington disease genetic testing Am J Hum Genet 62:1243-1247.

Aziz NA, Jurgens CK, Landwehrmeyer GB, EHDN Registry Study Group, van Roon-Mom WM, van Ommen GJ, Stijnen T, Roos RA. 2009. Normal and mutant $H T T$ interact to affect clinical severity and progression in Huntington's disease. Neurology 73:1280-1285.

Aziz NA, van Belzen MJ, Coops ID, Belfroid RD, Roos RA. 2011. Parent-oforigin differences of mutant HTTCAG repeat instability in Huntington's disease. Eur J Med Genet 54:e413-e418.

Brocklebank D, Gayan J, Andresen JM, Roberts SA, Young AB, Snodgrass SR, Penney JB, Ramos-Arroyo MA, Cha JJ, Rosas HD, Hersch SM, Feigin A, Cherny SS, Wexler NS, Housman DE, Cardon LR. InternationalVenezuela Collaborative Research Group. 2009. Repeat instability in the 27-39 CAG range of the HD gene in the Venezuelan kindreds: counseling implications Am J Med Genet Part B Neuropsychiatr Genet 150B:425-429.

Costa MC, Magalhaes P, Ferreirinha F, Guimaraes L, Januario C, Gaspar I, Loureiro L, Vale J, Garrett C, Regateiro F, Magalhaes M, Sousa A, Maciel P, Sequeiros J. 2003. Molecular diagnosis of Huntington disease in Portugal: implications for genetic counseling and clinical practice. Eur J Hum Genet 11:872-878.

Cottrell CE, Mendell J, Hart-Kothari M, Ell D, Thrush DL, Astbury C, Pastore M, Gastier-Foster JM, Pyatt RE. 2012. Maternal uniparental disomy of chromosome 4 in a patient with limb-girdle muscular dystrophy 2E confirmed by SNP array technology. Clin Genet 81:578-583.

Ding Q, Ouyang Q, Xi X, Wang X, Shen Y, Wang H. 2012. Maternal chromosome 4 heterodisomy/isodisomy and $\mathrm{B} \equiv$ chain Trp323X mutation resulting in severe hypodysfibrinogenaemia. Thromb Haemost 108:654-661.

Djousse L, Knowlton B, Hayden M, Almqvist EW, Brinkman R, Ross C, Margolis R, Rosenblatt A, Durr A, Dode C, Morrison PJ, Novelletto A, Frontali M, Trent RJ, McCusker E, Gomez-Tortosa E, Mayo D, Jones R, Zanko A, Nance M, Abramson R, Suchowersky O, Paulsen J, Harrison M, Yang Q, Cupples LA, Gusella JF, MacDonald ME, Myers RH. 2003. Interaction of normal and expanded CAG repeat sizes influences age at onset of Huntington disease. Am J Med Genet A 119A:279-282.

Durr A, Hahn-Barma V, Brice A, Pecheux C, Dode C, Feingold J. 1999. Homozygosity in Huntington's disease. J Med Genet 36:172-173.

Elli FM, Ghirardello S, Giavoli C, Gangi S, Dioni L, Crippa M, Finelli P, Bergamaschi S, Mosca F, Spada A, Beck-Peccoz P. 2012. A new structural arrangement associated to Wolfram syndrome in a child with a partial phenotype. Gene 509:168-172.

Engel E. 2006. A fascination with chromosome rescue in uniparental disomy: Mendelian recessive outlaws and imprinting copyrights infringements. Eur J Hum Genet 14:1158-1169.

Evans SJ, Douglas I, Rawlins MD, Wexler NS, Tabrizi SJ, Smeeth L. 2013. Prevalence of adult Huntington's disease in the UK based on diagnoses 
recorded in general practice records. J Neurol Neurosurg Psychiatry 84:1156-1160.

Fisher ER, Hayden MR. 2014. Multisource ascertainment of Huntington disease in Canada: prevalence and population at risk. Mov Disord 29:105-114.

Goldberg YP, Kremer B, Andrew SE, Theilmann J, Graham RK, Squitieri F, Telenius H, Adam S, Sajoo A, Starr E, Heiberg A, Wolff G, Hayden M. 1993. Molecular analysis of new mutations for Huntington's disease: intermediate alleles and sex of origin effects. Nat Genet 5:174-179.

Goldberg YP, McMurray CT, Zeisler J, Almqvist E, Sillence D, Richards F, Gacy AM, Buchanan J, Telenius H, Hayden MR. 1995. Increased instability of intermediate alleles in families with sporadic Huntington disease compared to similar sized intermediate alleles in the general population. Hum Mol Genet 4:1911-1918.

Huntington's Disease Collaborative Research Group. 1993. A novel gene containing a trinucleotide repeat that is expanded and unstable on Huntington's disease chromosomes Cell 72:971-983.

Kotzot D. 2008. Complex and segmental uniparental disomy updated. J Med Genet 45:545-556.

Kremer B, Goldberg P, Andrew SE, Theilmann J, Telenius H, Zeisler J, Squitieri F, Lin B, Bassett A, Almqvist E, Bird TD, Hayden MR. 1994. A worldwide study of the Huntington's disease mutation: the sensitivity and specificity of measuring CAG repeats. N Engl J Med 330:1401-1406.

Kremer B, Almqvist E, Theilmann J, Spence N, Telenius H, Goldberg YP, Hayden MR. 1995. Sex-dependent mechanisms for expansions and contractions of the CAG repeat on affected Huntington disease chromosomes. Am J Hum Genet 57:343-350.

Kuchinka BD, Barrett IJ, Moya G, Sanchez JM, Langlois S, Yong SL, Kalousek DK, Robinson WP. 2001. Two cases of confined placental mosaicism for chromosome 4, including one with maternal uniparental disomy. Prenat Diagn 21:36-39.

Laccone F, Engel U, Holinski-Feder E, Weigell-Weber M, Marczinek K, Nolte D, Morris-Rosendahl DJ, Zuhlke C, Fuchs K, Weirich-Schwaiger H, Schluter G, von Beust G, Vieira-Saecker AM, Weber BH, Riess O. 1999. DNA analysis of Huntington's disease: five years of experience in Germany, Austria and Switzerland Neurology 53:801-806.

Laccone F, Christian W. 2000. A recurrent expansion of a maternal allele with 36 CAG repeats causes Huntington disease in two sisters. Am J Hum Genet 66:1145-1148.

Lee JM, Ramos EM, Lee JH, Gillis T, Mysore JS, Hayden MR, Warby SC, Morrison P, Nance M, Ross CA, Margolis RL, Squitieri F, Orobello S, Di Donato S, Gomez-Tortosa E, Ayuso C, Suchowersky O, Trent RJ, McCusker E, Novelletto A, Frontali M, Jones R, Ashizawa T, Frank S, Saint-Hilaire MH, Hersch SM, Rosas HD, Lucente D, Harrison MB, Zanko A, Abramson RK, Marder K, Sequeiros J, Paulsen JS, PREDICTHD study of the Huntington Study Group (HSG), Landwehrmeyer GB, REGISTRY study of the European Huntington's Disease Network, Myers RH, HD-MAPS Study Group, MacDonald ME, Gusella JF, COHORT study of the HSG. 2012 CAG repeat expansion in Huntington disease determines age at onset in a fully dominant fashion Neurology 78:690 695.

Lindor NM. 2009. Hereditary colorectal cancer: MYH-associated polyposis and other newly identified disorders. Best Pract Res Clin Gastroenterol 23:75-87.

Maat-Kievit A, Losekoot M, Van Den Boer-Van Den Berg H, Van Ommen GJ, Niermeijer M, Breuning M, Tibben A. 2001a. New problems in testing for Huntington's disease: the issue of intermediate and reduced penetrance alleles. J Med Genet 38:1-5.

Maat-Kievit A, Helderman-van den Eden P, Losekoot M, de Knijff P, Belfroid R, Vegter-van der Vlis M, Roos R, Breuning M, 2001b. Using a roster and haplotyping is useful in risk assessment for persons with intermediate and reduced penetrance alleles in Huntington disease. Am J Med Genet 105:737-744.

Middleton FA, Trauzzi MG, Shrimpton AE, Gentile KL, Morley CP, Medeiros H, Pato MT, Pato CN. 2006. Complete maternal uniparental isodisomy of chromosome 4 in a subject with major depressive disorder detected by high density SNP genotyping arrays. Am J Med Genet B Neuropsychiatr Genet 141B:28-32.

Myers RH, Leavitt J, Farrer LA, Jagadeesh J, McFarlane H, Mastromauro CA, Mark RJ, Gusella JF. 1989. Homozygote for Huntington disease. Am J Hum Genet 45:615-618.

Potter NT, Spector EB, Prior TW. 2004. Technical standards and guidelines for Huntington disease testing. Genet Med 6:61-65.

Raskin S, Allan N, Teive HA, Cardoso F, Haddad MS, Levi G, Boy R, Lerena J, Sotomaior VS, Janzen-Duck M, Jardim LB, Fellander FR, Andrade LAF. 2000. Huntington disease: DNA analysis in Brazilian population. Arq Neuropsiquiatr 58:977-985.

Sanchez A, Castellvi-Bel S, Mila M, Genis D, Calopa M, Jimenez D, Estivill X. 1996. Huntington's disease: confirmation of diagnosis and presymptomatic testing in Spanish families by genetic analysis. J Neurosurg Psychiatry 61:625-627.

Sanchez A, Mila M, Castellvi-Bel S, Rosich M, Jimenez D, Badenas C, Estivill X. 1997. Maternal transmission in sporadic Huntington's disease. J Neurol Neurosurg Psychiatry 62:535-537.

Scionti I, Fabbri G, Fiorillo C, Ricci G, Greco F, D’Amico R, Termanini A, Vercelli L, Tomelleri G, Cao M, Santoro L, Percesepe A, Tupler R. 2012. Facioscapulohumeral muscular dystrophy: new insights from compound heterozygotes and implication for prenatal genetic testing. J Med Genet 49:171-178.

Semaka A, Creighton S, Warby S, Hayden MR. 2006. Predictive testing for Huntington disease: interpretation and significance of intermediate alleles. Clin Genet 70:283-294.

Semaka A, Collins JA, Hayden MR. 2010. Unstable familial transmissions of Huntington disease alleles with 27-35 CAG repeats (intermediate alleles). Am J Med Genet Part B 153B:314-320.

Semaka A, Kay C, Doty C, Collins JA, Bijlsma EK, Richards F, Goldberg YP, Hayden MR. 2013a. CAG size-specific risk estimates for intermediate allele repeat instability in Huntington disease. J Med Genet 50:696703.

Semeka A, Kay C, Doty CN, Collins JA, Tam N, Hayden MR. 2013b. High frequency of intermediate alleles on Huntington disease-associated haplotypes in British Columbia's general population. Am J Med Genet Part B 162B:864-871.

Semaka A, Hayden MR. 2014. Evidence-based genetic counseling implications for Huntington disease intermediate allele predictive test results. Clin Genet 85:303-311.

Semaka A, Kay C, Belfroid RD, Bijlsma EK, Losekoot M, van Langen IM, van Maarle MC, Oosterloo M, Hayden MR, van Belzen MJ. 2015. A new mutation for Huntington disease following maternal transmission of an intermediate allele. Eur J Med Genet 58:28-30.

Sequeiros J, Ramos EM, Cerqueira J, Costa MC, Sousa A, Pinto-Basto J, Alonso I. 2010. Large normal and reduced penetrance alleles in Huntington disease: instability in families and frequency at the laboratory, at the clinic and in the population. Clin Genet 78:381-387.

Shi SS, Lin Y, Zhao GX, Gan SR, Wu ZY. 2012. A Chinese pedigree with an individual homozygous for CAG repeats of Huntington's disease. Psychiatr Genet 22:53-54.

Snell RG, MacMillan JC, Cheadle JP, Fenton I, Lazarou LP, Davies P, MacDonald ME, Gusella JF, Harper PS, Shaw DJ. 1993. Relationship between trinucleotide repeat expansion and phenotypic variation in Huntington's disease. Nat Genet 4:393-397. 
Spena S, Duga S, Asselta R, Peyvandi F, Mahasandana C, Malcovati M, Tenchini ML. 2004. Congenital afibrinogenaemia caused by uniparental disomy of chromosome 4 containing a novel $15-\mathrm{kb}$ deletion involving fibrinogen A $\alpha$-chain gene. Eur J Hum Genet 12:891-898.

Squitieri F, Gellera C, Cannella M, Mariotti C, Cislaghi G, Rubinsztein DC, Almqvist EW, Tuner D, Bachoud-Levi AC, Simpson SA, Delatycki M, Maglione V, Hayden MR, Donato SD. 2003a. Homozygosity for CAG mutation in Huntington disease is associated with a more severe clinical course. Brain 126:946-955.

Squitieri F, Almqvist EW, Cannella M, Cislaghi G, Hayden MR. 2003b. Predictive testing for persons at risk for homozygosity for CAG expansion in the Huntington disease gene. Clin Genet 64:524-525.

Squitieri F, Jankovic J. 2012. Huntington's disease: how intermediate are intermediate repeat lengths? Mov Disord 27:1714-1717.

Tassiker RJ, Marshall PK, Liebeck TA, Keville MA, Singaram BM, Richards FH. 2006. Predictive and pre-natal testing for Huntington disease in Australia: results and challenges encountered during a 10-year period (1994-2003). Clin Genet 70:480-489.

Warby SC, Graham RK, Hayden MR. Huntington Disease. 1998. Oct 23 [Updated 2014 Dec 11]. In: Pagon RA, Adam MP, Ardinger $\mathrm{HH}$, et al., editors. GeneReviews ${ }^{\mathrm{TM}}$ [Internet]. Seattle (WA): University of Washington, Seattle; 1993-. Available from: http://www.ncbi.nlm.nih. gov/books/NBK1305/.

Wexler NS, Young AB, Tanzi RE, Travers H, Starosta-Rubinstein S, Penney JB, Snodgrass SR, Shoulson I, Gomez F, Ramos-Arroyo MA, Penchaszadeh GK, Moreno H, Gibbons K, Faryniarz A, Hobbs W, Anderson MA, Bonilla E, Conneally PM, Gusella JF. 1987. Homozygotes for Huntington's disease. Nature 326:194-197.

Wexler NS, Lorimer J, Porter J, Gomez F, Moskowitz C, Shackell E, Marder K, Penchaszadeh G, Roberts SA, Gayán J, Brocklebank D, Cherny SS,
Cardon LR, Gray J, Dlouhy SR, Wiktorski S, Hodes ME, Conneally PM, Penney JB, Gusella J, Cha JH, Irizarry M, Rosas D, Hersch S, Hollingsworth Z, MacDonald M, Young AB, Andresen JM, Housman DE, De Young MM, Bonilla E, Stillings T, Negrette A, Snodgrass SR, MartinezJaurrieta MD, Ramos-Arroyo MA, Bickham J, Ramos JS, Marshall F, Shoulson I, Rey GJ, Feigin A, Arnheim N, Acevedo-Cruz A, Acosta L, Alvir J, Fischbeck K, Thompson LM, Young A, Dure L, O’Brien CJ, Paulsen J, Brickman A, Krch D, Peery S, Hogarth P, Higgins DS Jr, Landwehrmeyer B. U.S. -Venezuela Collaborative Research Project. 2004. Venezuelan kindreds reveal that genetic and environmental factors modulate Huntington's disease age of onset PNAS 101:3498-3503.

Yamazawa K, Ogata T, Ferguson-Smith AC. 2010. Uniparental disomy and human disease: an overview. Am J Med Genet Part C Semin Med Genet 154C:329-334.

Yao RE, Wang J, Geng J, Zheng Z, Yu T, Yu Y, Fu Q. 2012. Identification of LDLR mutations in two Chinese pedigrees with familial hypercholesterolemia. J Pediatr Endocr Metab 25:769-773.

Youngblom E, Knowles JW. 2014. Jan 2. Familial hypercholesterolemia. In: Pagon RA, Adam MP, Ardinger $\mathrm{HH}$, et al., editors. GeneReviews ${ }^{\mathrm{TM}}$ [Internet]. Seattle (WA): University of Washington, Seattle; 1993-. Available from: http://www.ncbi.nlm.nih.gov/books/NBK174884/.

Young AB, Shoulson I, Penney JB, Starosta-Rubinstein S, Gomez F, Travers H, Ramos-Arroyo MA, Snodgrass SR, Bonilla E, Moreno H, Wexler NS. 1986. Huntington's disease in Venezuela: Neurologic features and functional decline. Neurology 36:244-249.

\section{SUPPORTING INFORMATION}

Additional supporting information may be found in the online version of this article at the publisher's web-site. 